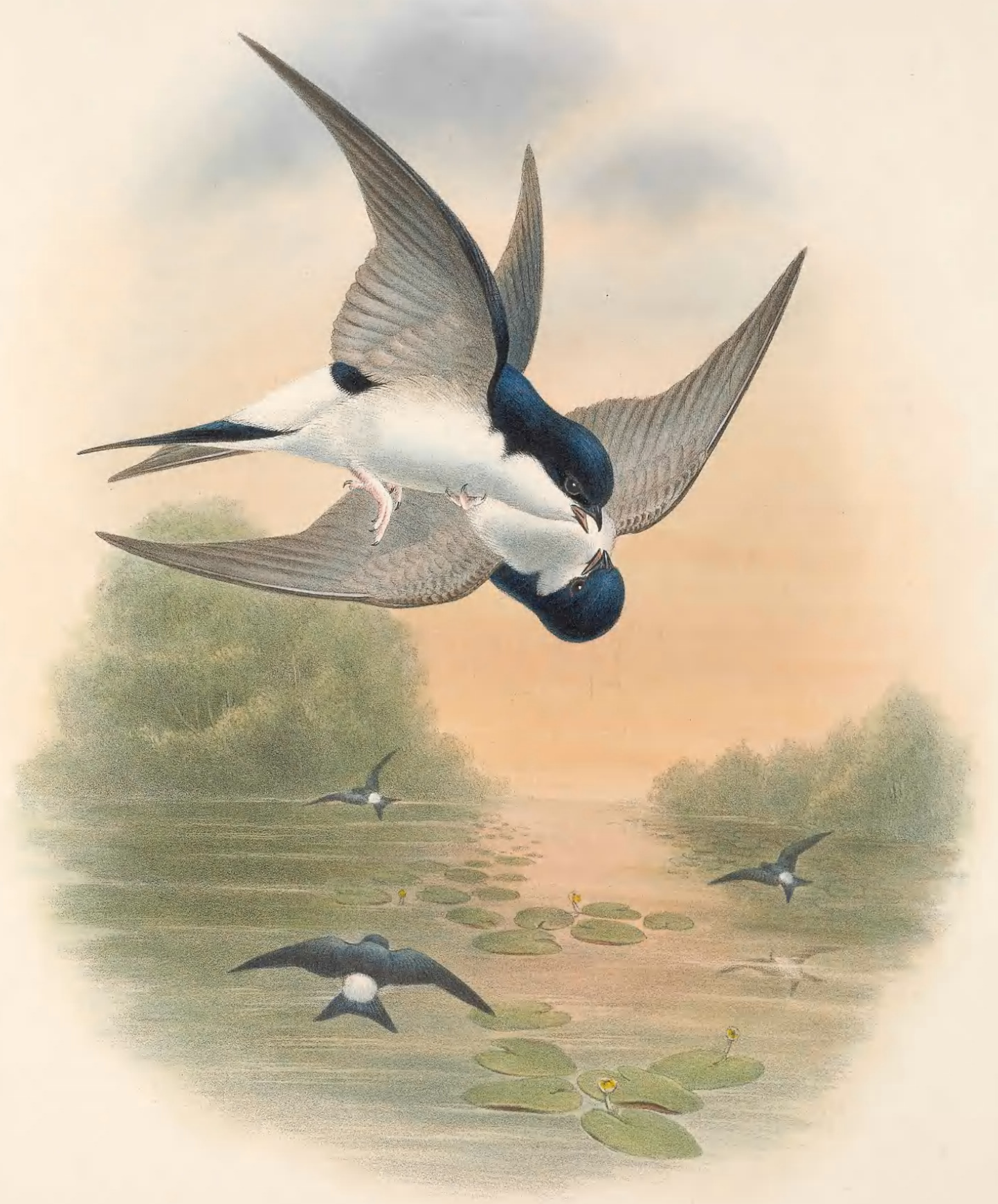




\section{CHELIDON URBICA.}

\section{House-Martin.}

Hirundo urbica, Linn. Faun. Suec., p. 98. domestica, Leach, Syst. Cat. of Indig. Mamm. and Birds in Coll. Brit. Mus., p. 19. sociabilis, Bailly, Orn. de la Savoie, tom. i. p. 268.

Chelidon urbica, Boie, Isis, 1822, p. 550. fenestrarum et C. rupestris, Brehm, Vög. Deutschl., tom. i. p. 140.

Hirundo (Chelidon) urbica, Keys. und Blas. Wirbelth. Eur., p. 61.

I know of no group of our native birds the study of which would afford greater pleasure to the young student of nature than the family of Hirundines - the Swift, the Swallow, the Sand-and House-Martinseach being characterized by a peculiarity in their structure, habits, and economy, and their modes of incubation being strikingly different, as will be seen on reference to my account of the respective species. All these birds are associated with summer; for it is at that season alone that they appear among us, gladdening our hearts with their presence, and exciting our admiration by their graceful evolutions during flight. Occasionally the mead is visited by all the species at the same time; and it is then that the difference in their modes of flight may be observed to the greatest advantage. The bold, sweeping action of the Swift enables him to outstrip the others with ease; the Swallow, with its lengthened tail, makes many rapid and graceful turns when engaged in the capture of insects, while the flight of the Sand- and House-Martins, though not without many elegant movements, appears to be more laboured; when thus engaged, the fairylike House-Martin, although shorter and more robust than its congeners, attracts greater attention than either of the others, in consequence of the white spot on the rump showing very conspicuously as the bird glides away in the distance or glances about in the sun, and presenting a great contrast to the adjoining darktinted plumage and the water over which the bird may be flying. While it must be conceded that all the species evince but little fear of man, the Martin is by far the most familiar of them ; for it apparently loves to be among us, and seems to court our intimacy and friendship more than the others. If its neatly built mud nest be destroyed, it neither takes offence nor harbours malice, but immediately commences another near the same site, or on the other side of the house, but generally at the corner of a window. We may reasonably assume that there was a time when there were no houses under which to make its nest, nor man to afford it protection, in which case the sides of rocks and shelving cliffs were the places sought for the purposes of incubation; and even at the present day such situations are resorted to; for Dr. Percy has very kindly called my attention to the circumstance of its still building in the rocks of Port Neath, Vaughan, in the vale of Neath, his authority for the fact being Mr. Edward Young, a very good observer, who has paid considerable attention to natural history. On the other hand, if a new dwelling be erected, far distant from other houses, the House-Martin soon appears, and commences building under the newly-formed eaves or at the angles of the windows; at least I observed it so to do at a recently erected residence at Auchnashalloch, in Ross-shire; and I trust that Mr. Tennent has afforded these welcome strangers a happy home during their sojourn in the beautiful valley of the Carron. That the Martin is neither capricious nor ungrateful for such protection, I can readily believe; for, if not overtaken by misfortune during its winter residence in foreign climes, the same individual will return to the spot where, the last year, or for years before, it had been allowed to remain undisturbed; and, in confirmation of this, I append a note forwarded to me by Mr. Philip Crowley, of Alton, in Hampshire, a gentleman fully imbued with a love for nature, and intimately acquainted with our native birds. It is dated July 8th, 1852, at which time he was resident at Grove House, Tottenham, Middlesex. "The two Martins I caught, labelled, and set at liberty last year, have returned. I tied a small piece of parchment to one leg of each, and wrote on it, 'P. Crowley, Alton, Hants, England,' and on the other side of one of them I now find, 'Don Vangello, Barcelona.' "'

"That the House-Martin not only visits the same place," says Captain King, in his "Narrative of a Journey to the Shores of the Arctic Regions in 1833-35,' " but the same nest year after year, is a fact which I ascertained by experiment. While residing in Kent, about ten years ago, having selected a detached nest, I fastened a small piece of silk round one of the legs of its inmate, then sitting upon eggs. The following season the bird returned, and, with the garter still affixed, was secured in the same nest-a convincing proof of the instinctive knowledge attributed to it." In confirmation of the above statement, Mr. Durham Weir informed Macgillivray that he caught several pairs of Martins at the windows of his house in September, 1838, and fixed small silver rings round their legs, and that one of them was shot, in his immediate neighbourhood, the following May. 
I have stated that the House-Martin, like its congeners, is a summer visitant only, arriving in spring, at the appointed time, almost to a day; this is neither early nor late in the season, generally about the middle of April; thus it is later in its arrival than the Sand-Martin and Swallow, and earlier than the Swift, which does not appear until the beginning of May. Where, then, does the fairy little Martin spend its days when not with us? We have seen, from Mr. Crowley's note, that it certainly goes to Spain; and, in my opinion, it proceeds still further south to Morocco, the winter quarters of by far the greater portion of our migrants. So much is generally known respecting this bird that it is scarcely necessary for me to state it is found in all parts of Britain, and that it is equally numerous in the warm lowlands as on the sides of the bleakest mountains; wherever human habitations exist, there assuredly will be found this pleasing wanderer. In all these situations it rears one or two broods a year, according to the more or less favourable state of the season. It is believed that as soon as the duty of incubation has been completed and the young are able to assist themselves, the old birds forsake their progeny and wing their way back to whence they came, leaving instinct to perform its wonderful power of guiding the young to the " unknown land" to which their parents have preceded them. Besides the British Islands, the House-Martin ranges as far north as the Ferroe Islands and Iceland; it is also found in every part of Europe, from the shores of the Mediterranean to Uleabourg; as with us, it is everywhere a summer sprite, whose appearance gladdens the hearts of the inhabitants, assuring them by its appearance that summer is not far behind. I am not satisfied that it is not found in other countries further east; at the same time I much question whether the assertion of its being a native of Amoorland, Kamtschatka, and even China be correct; indeed I feel assured that the bird is not found therein, but that the species mistaken for it is probably the one I have called Chelidon Cashmiriensis, which may also be the bird Mr. Jerdon speaks of in his 'Birds of India,' under the name of English House-Martin, as having been found by him in small numbers, in one locality, on the Neilgherries. It may, however, extend its range throughout Persia, to the confines of India ; but we have no direct evidence of the fact. The Rev. H. B. Tristram states that " it is the last of the Swallow tribe to return to Palestine, where it appears in great numbers about April 5 th, and breeds in colonies on the sheltered faces of cliffs in the valleys of northern Galilee." The chief differences between C. Cashmiriensis and C. urbica is the smaller size of the former, and particularly the darker colours of its axillary feathers.

"The ease and rapidity of its flight, however marvellous, excites no astonishment, as we are daily in the habit of witnessing them," says Macgillivray; " but a true lover of nature can, nevertheless, contemplate its airy windings for hours with delight. The evolutions of this s pecies resemble, in all respects, those of the Swallow; but its flight is perhaps somewhat less rapid, although it is certainly very difficult to decide with accuracy in a comparison of this kind. Its sweeps and curves, however, seem to me less bold, or, rather, less extended; but its dexterity is equally remarkable. The influence of the weather on the flight of insects causes it to observe the same selection of places that they do; so that, in calm and cloudless days it flies more in the open air, in windy weather more in the shelter of hedges and walls, and in damp evenings it skims over the grass and corn."

To give some idea of the numbers of insects which these birds capture to feed their young, besides those taken for their own support, I may mention that one of Macgillivray's correspondents informed him that a pair of Martins began to feed their young ones, four in number, at twenty-five minutes after four o'clock in the morning; and at ten minutes after eight in the evening, when they ceased from their labours, they had fed them no less than 307 times : this was on a bright sunny day; on a subsequent dull rainy one, they only fed them 212 times.

The male Martin slightly differs from the female in size, being smaller, and having a less forked tail ; in other respects the two sexes are externally alike.

The nest, which is built of pellets of mud collected by the bird, is lined with a layer of straws, and sometimes wool, and, lastly, a number of feathers ; the eggs are four or five in number, of a pure white, without spots, but with a blush of flesh-colour showing through the almost transparent shell.

The two figures, in the upper part of the Plate, are of the natural size. 


\section{$2 \mathrm{BHL}$ Biodiversity Heritage Library}

Gould, John. 1873. "House-Martin, Chelidon urbica [PI. 6]." The birds of Great Britain 2, -. https://doi.org/10.5962/p.323822.

View This Item Online: https://www.biodiversitylibrary.org/item/221554

DOI: https://doi.org/10.5962/p.323822

Permalink: https://www.biodiversitylibrary.org/partpdf/323822

\section{Holding Institution}

Smithsonian Libraries

\section{Sponsored by}

Biodiversity Heritage Library

\section{Copyright \& Reuse}

Copyright Status: Public domain. The BHL considers that this work is no longer under copyright protection.

This document was created from content at the Biodiversity Heritage Library, the world's largest open access digital library for biodiversity literature and archives. Visit BHL at https://www.biodiversitylibrary.org. 